Schulich School of Law, Dalhousie University

Schulich Law Scholars

Research Papers, Working Papers, Conference

Papers

Faculty Scholarship

4-23-2011

\title{
Indonesia's Refusal to Share Influenza Virus Specimens with the World: Reviving the Arguments for Justice in Influenza Pandemic Preparedness
}

Matthew Herder

Dalhousie University, matthew.herder@dal.ca

Meena Krishnamurthy

University of Manitoba, Meena.Krishnamurthy@gmail.com

Follow this and additional works at: https://digitalcommons.schulichlaw.dal.ca/working_papers

Part of the Health Law and Policy Commons, and the Intellectual Property Law Commons

\section{Recommended Citation}

Matthew Herder, "Indonesia's Refusal to Share Influenza Virus Specimens with the World: Reviving the Arguments for Justice in Influenza Pandemic Preparedness" (2011) Dalhousie University Schulich School of Law No 23.

This Working Paper is brought to you for free and open access by the Faculty Scholarship at Schulich Law Scholars. It has been accepted for inclusion in Research Papers, Working Papers, Conference Papers by an authorized administrator of Schulich Law Scholars. For more information, please contact hannah.steeves@dal.ca. 


\title{
Indonesia's Refusal to Share Influenza Virus Specimens with the World: Reviving the Arguments for Justice in Influenza Pandemic Preparedness
}

\author{
Meena Krishnamurthy, Ph.D. \\ Assistant Professor, Department of Philosophy \\ University of Manitoba \\ 453 University College \\ Winnipeg, MB R3T 2N2 Canada \\ Phone: (204) 474-6878 Fax: (204) 474-7586 \\ Meena.Krishnamurthy@gmail.com \\ Matthew Herder, LL.M., J.S.M. \\ Assistant Professor, Faculty of Medicine \\ Dalhousie University \\ 5849 University Avenue \\ Halifax, NS B3H 4H7 Canada \\ Phone: (902) 494-3801 Fax: (902) 494-2567 \\ Matthew.Herder@Dal.ca
}

Word Count: 5, 831

Key Words: Influenza, Pandemic, Justice, World Health Organization, Indonesia

\begin{abstract}
: (149 words)
Indonesia's December 2006 decision to stop sending influenza virus specimens to the World Health Organization's Global Influenza Surveillance Network (GISN) captured international attention. At the time, the H5N1 subtype of influenza A virus was predicted to be the basis for the next pandemic. While many accused Indonesia - the country most afflicted by the virus - of putting the rest of the world in peril by withholding virus samples, Indonesia maintained that GISN was unjust for failing to ensure equitable access to vaccines developed using those samples. The H5N1 pandemic threat eventually waned, yet international negotiations to create a just framework for "sharing influenza viruses and other benefits" are ongoing.

In this paper, we critically evaluate Indonesia's claims about the unjustness of GISN. We argue in favour of Indonesia's position and conclude that GISN must be significantly altered so that it properly recognizes the values of ownership, contribution, reciprocity, and human rights.
\end{abstract}

Acknowledgements

Research funded by the Canadian Institutes of Health Research Grant No. PAN83161, "Pandemic Planning and Foundational Questions of Justice, the Common Good and the Public Interest." Thanks go to Françoise Baylis, Josephine Johnston, and Anthony Skelton as well as members of Novel Tech Ethics at Dalhousie University for helpful comments on an earlier draft of the paper. 


\section{Indonesia's Refusal to Share Influenza Virus Specimens with the World: Reviving the Arguments for Justice in Influenza Pandemic Preparedness}

Indonesia's December 2006 decision to stop sending influenza virus specimens to the World Health Organization's (WHO) Global Influenza Surveillance Network (GISN) - a longstanding, complex, hierarchical network comprised of WHO Collaborating Centers, Reference Laboratories, and National Influenza Centers - captured international attention. At the time, the H5N1 subtype of influenza A virus, was predicted to be the basis for the next pandemic. Indonesia, the country most afflicted by the virus, was accused of putting the rest of the world in peril by withholding samples that were vital to the development of an effective vaccine. ${ }^{1}$ Eventually, Indonesia resumed sending virus specimens to GISN, but its actions - which were largely done in protest of the unjustness of GISN - stimulated negotiations to improve the workings of GISN by developing and implementing a more just framework for "sharing influenza viruses and other benefits." 2

Now, after four and a half years of negotiations, a new framework (comprised of a standardized MTA and an accompanying set of benefit-sharing principles) will be debated at the World Health Assembly (WHA) meeting in May 2011. Though it remains an open question as to whether this framework will be ratified by a majority of member states, given the diverging interests of developed versus developing countries, ${ }^{3}$ if the WHO is somehow able to broker the deal, there is enthusiasm for what the framework promises. One source describes that framework as a "multilateral governance of intellectual property rights," in which the WHO would mediate the exchange of intellectual property rights amongst multiple public institutions and private firms. Judged against that outcome, Indonesia's decision to stop sending virus specimens to the WHO might, in hindsight, be seen to have done some good.

Our goal here, however, is not to assess the justness of Indonesia's withholding of virus samples, but rather to develop and critically examine some of Indonesia's claims about the unjustness of the framework for benefit sharing in GISN. We begin by outlining the facts of the Indonesian case and the main elements of the recent policy proposals advanced to address concerns regarding virus and benefit sharing in GISN. We then develop and evaluate four possible lines of argument - based on the values of ownership, contribution, reciprocity, and human rights - that could be used to bolster Indonesia's claims about the unjustness of GISN's framework for benefit sharing. While we derive these arguments from claims made by representatives of the Indonesian government during the controversy, here we aim to present them in a more fulsome way. We show that the arguments from ownership, contribution, and reciprocity work together to support Indonesia's claim that it is owed a greater share in the benefits of GISN. We then show that an additional argument based on human rights, which Indonesia did not directly invoke, is more straightforward and has more far reaching implications than the other arguments, insofar as it establishes, for all developing countries, a claim to a greater share of the benefits of GISN. 


\section{Sequence of Events}

In February 2004 influenza re-emerged amongst Indonesian fowl. Lacking incountry capacity to distinguish between influenza strains, Indonesia provided GISN scientists with virus specimens. In July 2005 the first human case of H5N1 in Indonesia was confirmed. Earlier that year, the WHO outlined the parameters for that very sort of collaboration amongst GISN members. Designated "WHO Reference laboratories" that receive virus specimens were to "seek permission from the originating country/laboratory to co-author and/or publish results obtained from the analyses of relevant viruses/samples," and "no further distribution of viruses/specimens outside the network of WHO Reference Laboratories [was to occur] without permission from the originating country/laboratory." With the help of the WHO and developed countries, Indonesia meanwhile built up its influenza virus identification and characterization capacity.

During 2005 and 2006, as the number of H5N1 human cases began to grow in Indonesia and many other parts of South-East Asia, Indonesia shared by far the largest number of virus specimens with GISN laboratories, including the U.S. Centers for Disease Control and Prevention (CDC) in Atlanta, Georgia, as well as Hong Kong University (see Figure 1). ${ }^{6}$ According to Indonesian officials, a series of incidents during this period, first frustrated, then halted altogether this exchange. Contrary to the WHO's 2005 guidance, scientific presentations and papers were produced using information derived from virus specimens supplied by Indonesia with little-to-no notice or genuine offer of co-authorship. Near the end of 2006, a journalist informed Indonesia's Ministry of Health that an Australia-based company, CSL Ltd., was in the process of developing a vaccine based on a "seed virus" derived from a virus specimen collected in Indonesia, but sent to GISN laboratories for further analysis. ${ }^{7}$ Subsequent reports confirmed that members of GISN routinely shared information derived from virus specimens with firms that were outside of the network, and that some GISN member institutions and private firms filed patent applications using that information. ${ }^{8}$

Following these developments, Indonesia's then Minister of Health, Siti Fadilah Supari, announced on December 20, 2006 the country's intention to stop sharing virus specimens with GISN. At the time, Indonesia had the highest number of confirmed H5N1 human cases and deaths in the world. As Indonesia followed through on that decision in January 2007, the WHO removed its 2005 guidance about sharing virus specimens from the world wide web, stressing instead that countries have a responsibility to share, unconditionally, virus specimens with the WHO so as not to "inhibit the proper functioning of the GISN... and the achievement of the Network's objectives." WHO officials travelled to Indonesia in February 2007 hoping to persuade through diplomacy, but Indonesia stood its ground and began side negotiations with Baxter International to secure a store of affordable vaccines for its population. A month later, after a meeting attended by representatives from thirty-three countries, Indonesia countered the WHO's call for responsibility with a rights-based claim, the "Jakarta Declaration," in which it asserted ownership over virus specimens and, in turn, a right to informed consent prior to distribution of virus specimens to anyone within or outside GISN. Thus, the debate over the balance between risks to the world writ large (posed by Indonesia's stance) and risks to the world's poor (which Indonesia argued GISN failed to address) quickly assumed a legal character. Whereas many in the international community posited that Indonesia 
was in violation of its obligations to communicate public health information that may constitute a "public health emergency of international concern" under the 2005

International Health Regulations (IHRs), Indonesia asserted its ownership over virus specimens under the Convention on Biological Diversity $(C B D)$, which accords countries sovereignty over their "biological and genetic resources."

The tension between responsibilities versus rights carried through to the WHA meeting in late May 2007, at which point seventeen new H5N1 human cases confirmed by Indonesia, sometime between then and January 2007, were made known to GISN (Again, see Figure 1). Although offers of financial aid made by developed countries in the interim failed to alter Indonesia's position, ${ }^{10}$ the WHA was able to secure resolution 60.28 at the last minute, setting up a working group to review the rules for sharing viruses and derivative information within and without GISN and requiring the Director-General to convene an intergovernmental working group to craft a more just (i.e., a more fair and equitable) benefit sharing scheme. ${ }^{11}$ In keeping with legal fashion, WHA 60.28 stops short of sorting out competing interests; its preamble simply recognizes both the sovereign rights of countries over biological and genetic resources and the importance of timely sharing of influenza virus specimen.

Bifurcating the issues between revising GISN's ground-rules on one hand, and vaccine access and benefit-sharing on the other, may have been a strategic mistake while Indonesia's holdout continued and other countries afflicted with H5N1, Viet Nam and Thailand, contemplated holding out as well. Intergovernmental meetings in Singapore in July 2007 and in Geneva in November 2007 were unproductive as efforts to revise GISN's terms and conditions were derailed by countries politicizing and positioning themselves around the benefit-sharing issue. For example, the first two days of the fourday Singapore meeting were allocated to crafting new standard terms and conditions for virus and information sharing within GISN. However, those discussions were repeatedly interrupted by questions and concerns about Indonesia's stance and benefit-sharing generally - the issue allocated for days three and four. Meanwhile, although specimens derived from two Indonesian patients were sent to the CDC in Atlanta in August 2007, the total of $\mathrm{H} 5 \mathrm{~N} 1$ cases not shared with the international community grew to thirtythree. $^{12}$

Through 2008 and 2009 the spread of H5N1 waned, a virus specimen tracking system was gradually implemented, Indonesia as well as other countries shifted to a practice of limited virus specimen sharing with GISN, and a new subtype of influenza A-H1N1 - cropped up in other regions of the world. The subsequent discovery of close ties between those at the WHO that decided to upgrade $\mathrm{H} 1 \mathrm{~N} 1$ to a pandemic threat and a handful of vaccine manufacturers that enjoyed windfall gains, have renewed questions about the WHO's integrity and, by extension, whose interests the GISN system serves. ${ }^{13}$ That and other controversies surrounding the H1N1 pandemic and the WHO have complicated the process of realizing a satisfactory benefit-sharing framework, ${ }^{14}$ which is ongoing.

Since May 2009, when WHA resolution 62.10 urged member states to conclude the "Pandemic Influenza Preparedness Framework," timely virus exchange and vaccine and other benefit sharing have been on the table: a standardized material transfer agreement (MTA) and Guiding Principles for the development of benefit sharing arrangements with influenza manufacturers (Guiding 
Principles). (See Figure 2, which depicts the diverging positions of less and more developed countries with respect to the scope of the MTA and whether intellectual property rights (or "IPRs") should be sought, and the compromise the WHO has proposed.) The former is a legal contract, now common with the exchange of biological materials, which requires a would-be recipient of materials to abide by certain terms and conditions set by the party in possession of those materials. For example, in the event of a dispute between a virus specimen provider and a member of GISN, the two parties are required to "seek an amicable settlement" before asking the WHO Director-General for a resolution. The latter is as its named: a statement of principles, which the WHO, without the legal authority to enforce, ${ }^{16}$ essentially hopes parties privy to and outside GISN will adhere to. The Guiding Principles highlight a number of different benefits-from vaccine donations, tiered pricing, or financial contributions to facilitate access to vaccines in developing countries in need, to transfer of influenza vaccine manufacturing technology - that benefit-sharing arrangements may include.

If the wording of the MTA - a legally enforceable contract — made adherence to the benefit-sharing principles mandatory, the WHO's lack of enforcement power might have represented less of a concern. Indeed, an MTA is the form of solution that Indonesia has been calling for all along (and claiming its sovereign rights over virus specimens, which in its view the $C B D$ entitled it to demand). However, the substance of the MTA has been repeatedly watered down relative to what Indonesia and other developing countries seem to have had in mind. Rather than creating contractually binding benefit-sharing obligations, the proposed MTA simply requests that private actors outside of GISN work up some form of benefit-sharing arrangement with the WHO. Rather than precluding GISN participants from seeking intellectual property rights, or at least making an upfront agreement to grant to the "WHO a royalty-free, nonexclusive, transferable license with respect to such rights" mandatory, the MTA's language has been softened, stating that those who seek intellectual property rights "should" grant such a license after-the-fact. ${ }^{17}$ If, and only if, there is a manufacturer with the wherewithal to make use of those intellectual property rights and produce, say, vaccines at cost for a poorer population, will such a license translate into access to affordable vaccines. Indeed, the draft MTA specifically highlights "commitment, ability and readiness of a potential recipient to use the sub-license" as the kind of circumstances in which such licensing would occur. Not surprisingly, then, two meetings of the WHO Executive Board in January of 2010 and 2011, as well as another WHA meeting in May 2010, have failed to translate into a finalized virus and benefit-sharing framework.

As Fidler summarizes the situation, developed countries "have not agreed to binding arrangements on more equitable access but, rather, attempt to increase access through ad hoc, reactive, and non-binding activities that preserve national freedom of action while demonstrating some humanitarian concern." ${ }^{\prime 18} \mathrm{H} 1 \mathrm{~N} 1$ offers a case in point: vaccines secured by advance purchase commitments between developed country governments and private manufacturers were sent to the developing world only after they were deemed surplus of national need. Like Fidler, we believe that global pandemic preparedness requires a diversified vaccine supply, and solving that collective action problem represents a critical challenge. In contrast to Fidler, though, we do not believe calls for greater "equity and justice" in pandemic preparedness are merely rhetoric. Building the moral foundations of a just framework for global pandemic preparedness is, 
rather, essential to collective action: it not only builds the case for why a more equitable and just framework for benefit sharing should be developed and implemented, but it also gives us an indication of which among the various paths forward is most appropriate. ${ }^{19}$

In the remainder of this paper, we critically examine the strengths and weaknesses of the various moral arguments that Indonesia invoked for refusing to share virus specimens with GISN. We reference the law to the extent that Indonesia or others framed an argument in legal terms. However, on the assumption that legal ambiguities regarding, for example, the $C B D$ and the IHRs will persist, ${ }^{20}$ we do not rely on legal authority to resolve the arguments below.

\section{The Arguments}

The main concern of distributive justice is the fair allocation of benefits and burdens. Theories of distributive justice attempt to give principles for the fair distribution of such things. According to Indonesia, GISN was unjust because it distributed benefits unfairly: it allowed much of the benefits related to virus sharing, in particular, vaccines that resulted from virus sharing, to accrue among developed countries and left developing countries empty handed. ${ }^{21}$ In a global context, Indonesia can be understood as claiming that GISN was in violation of basic principles of distributive justice. In making its case for this claim, Indonesia appealed to a variety of different values. Specifically, Indonesia's arguments were based on the values of ownership (of virus specimens), contribution (to vaccine research and development and global pandemic preparedness) and reciprocity (amongst fellow GISN participants) — any one of which, according to Indonesia, merited return of benefits. In what follows, we will show that when considered individually each argument fails to establish Indonesia's claim to greater benefits, but when taken together they successfully establish such a claim. We also argue that, though Indonesia didn't explicitly make such an argument, the claim to greater benefits can be grounded in the value of human rights. We argue that this is the more straightforward and inclusive claim for benefit sharing.

\section{From Ownership}

According to Indonesia, GISN was unjust because it failed to provide adequate return for shared virus samples, which, under international law, Indonesia claimed to own. That Indonesia relied on this ownership argument as its primary attack on GISN was understandable: others availing of GISN were asserting patent rights over technological things such as genetic sequences of viruses, which, in Indonesia's estimation, would not have been produced but for virus samples that "belonged" to Indonesia. In the context of research and development, ownership is, it would seem, the means by which one asserts a claim to the products of a value chain.

However, as a matter of international law, Indonesia's claim of ownership over influenza virus specimens derived from humans is highly questionable. The $C B D$ provides nations with sovereignty over "biological and genetic resources," which theoretically includes viruses. However, biological and genetic resources isolated from humans have been exempted from the $C B D$ 's ambit. ${ }^{22}$ Furthermore, extending it to 
include human pathogenic viruses does not follow from the CBD's primary objects of promoting conservation and biodiversity. ${ }^{23}$

While the legality of whether Indonesia owned the virus samples may always be unclear, a moral case can be made on two different grounds in support of Indonesia's claims of ownership. The first ground is based on John Locke's labour-desert theory. Locke argues that, insofar as we own ourselves and our labour, we come to own that with which we mix our labour. For example, in picking a bushel of apples from a previously unowned apple orchard, we come to own those apples by mixing our labour with them.

Something similar might hold in the Indonesian case. Significant labour, on the part of the state, is required for the collection, analysis, and transport of virus samples. Public health officials who work at the behest of the state, must enter the point of contagion, collect samples from those who are suspected of infection, gather epidemiological data, return the samples to a domestic lab for preliminary and then antigenic and genetic analysis by technicians, or, in the event that the domestic lab lacks the capacity to complete these tasks, secure transportation to foreign institutions membered with GISN to complete the assessment and proceed with virus selection and vaccine development. So, even if the process stops well short of vaccine development in a given country, collection of virus specimens and epidemiological data constitutes a year-round activity, with discrete tasks such as virus isolation and preliminary analysis consuming multiple weeks of labour. ${ }^{24}$ From a Lockean perspective, then, given that Indonesia mixed its labour with the virus samples by virtue of collecting them and performing preliminary analyses, it came to have ownership over them.

The second moral ground relates to notions of self-ownership and rights of transfer. Virus samples that were shared with GISN by Indonesia came from Indonesian citizens who relinquished virus samples to the Indonesian state. Insofar as all humans are considered to have ownership (in a moral sense) over their bodies, it follows that Indonesian citizens had ownership over the viruses that were contained within their body. As virus specimens were collected, either from living or deceased individuals, we can conceive of this right of control being transferred to the Indonesian state - assuming, of course, proper consent was given for that transfer.

However, even if we grant that Indonesia owned the virus samples it contributed to GISN on the basis of one of these arguments, this only gets us part way toward establishing that they, or any other contributing country, are owed a share of the benefits associated with participating in GISN. Ownership is a kind of flag or marker: it helps identify who - if anyone - should be given return for a contribution to a productive process. If we decide that a particular contribution should be rewarded, the fact that you have ownership over that contribution suggests that you should receive something in return for the contribution. The notion of ownership, however, does not in itself give us any answers to other equally morally important questions regarding how much you are owed in return for your contribution or when you should receive something in return for your contribution in the first place. Some other values or principles must do this work. ${ }^{25}$

\section{From Contribution}

Embedded in Indonesia's claims about ownership is a claim for return on the basis of its contribution to productive processes. Without virus specimens collected 
within its borders both influenza surveillance and the research and development of an effective H5N1 vaccine would have been compromised. For these reasons, Indonesia held that it should be compensated for its contribution. Recall that in 2005 and 2006 Indonesia was by far the largest contributor of virus specimens to GISN (see Figure 1). Even in 2007, the year in which it suspended sharing for several months, it was the fifth largest contributor with sixty-two specimens sent to GISN (behind Egypt (145), Viet Nam (125), Nigeria (66), and Cambodia (64)). ${ }^{26}$

Contributions can, however, be evaluated in a variety of ways. In the context of GISN, we can imagine at least three ways of evaluating Indonesia's contribution: in terms of necessity; in terms of labour and capital costs; and, in terms of ability to contribute. As the preceding paragraph illustrates, Indonesia tied its claims about the significance of its contribution to necessity: its contribution of virus samples was necessary to vaccine production and, in turn, to global pandemic preparedness.

Developed countries and vaccine manufacturers might, and presumably did through diplomatic channels, challenge this claim. Extremely few virus isolates are selected for vaccine development. Of the $8,815 \mathrm{H} 5 \mathrm{~N} 1$ virus specimens shared with GISN between 2003 and 2007, only $14(0.16 \%)$ were used for vaccine development, and only one of which emanated from a specimen collected in Indonesia. And while virus specimens are a necessary initial input to the process and do require labour and capital costs, financing, research, technology, know-how, regulatory oversight, and the assumption of risk in the marketplace - most of which are currently supplied by private companies and developed country governments - represent most of the labour and capital costs associated with vaccine research and development. Thus, using labour and capital cost as our measure, Indonesia's contribution merits little in return.

In our view, though this labour and capital cost based account is a reasonable answer to Indonesia's contribution argument based on necessity, it is not a complete account of contribution. Focusing on labour and capital costs associated with virus collection versus vaccine research and manufacturing fails to account for fundamental differences in the ability of participants to contribute. Consider an analogy. A group of three people $\mathrm{X}, \mathrm{Y}$, and $\mathrm{Z}$ are hungry for pie with ice cream. Each of them contributes to the making of a pie. $X$ and $Y$ have significant pie-making resources available to them and are able to contribute more than $\mathrm{Z}$. X contributes all of the ingredients with the exception of sugar and ice cream, since he's run out of these items. Y, having none of the needed ingredients, contributes the relevant mixing utensils (spoons, bowls, etc.). $\mathrm{X}$ and $\mathrm{Y}$ also agree to take turns mixing the ingredients. $\mathrm{Z}$, however, is not so fortunate in her access to pie-making resources. Through no fault of her own, she is only able to contribute a scoop of ice cream to the process and is only able to do a few stirs, because of arm injuries. If, in deciding how to divide the pie, we were to focus on the labour and capital costs associated with the people's contributions, it is clear that X and Y's contributions are of greater significance than $Z$ 's. The labour that $X$ and $Y$ contribute, in terms of mixing, is much more than $Z$ 's, since $Z$ is able to give only a few stirs. And the cost of all the other ingredients and the mixing utensils is much more than a scoop of ice cream. For this reason, $\mathrm{X}$ and Y's contributions might be thought to merit a greater share of the pie than Z. If, however, we take into consideration the participant's abilities to contribute, we reach a different conclusion. $\mathrm{X}$ and $\mathrm{Y}$ have significant resources to contribute to the pie-making process. $\mathrm{Z}$ does not have significant resources to contribute. 
However, like $\mathrm{X}$ and $\mathrm{Y}, \mathrm{Z}$ contributes all that she can to the pie-making process. She just happens to have less to contribute than $X$ and $Y$. With this in mind, it seems that Z's contribution is as significant as $\mathrm{X}$ and $\mathrm{Y}$ 's and, in turn, that $\mathrm{Z}$, like $\mathrm{X}$ and $\mathrm{Y}$, is owed an equal share of the pie. This seems fair.

Something similar holds true in the case of Indonesia and its contribution to GISN. Indonesia didn't have the financial resources to contribute in other ways to GISN. Collected virus samples were all that it could contribute to GISN and the process of vaccine development and production. For this reason, the contributions that developing countries such as Indonesia make to GISN are as significant as the contributions made by developing countries (who, lacking virus specimens, contribute what they can in the way of technology and know-how, for example). In turn, their contributions warrant a share of the benefits that result from contribution to GISN that is equal to what developed countries receive. ${ }^{27}$

However, even if we accept that Indonesia's contribution is significant - either on the basis of necessity or ability to contribute - this is not enough to establish that Indonesia should be compensated for its virus sample contributions or that failing to compensate Indonesia for its contribution is unjust. Evaluations of contribution only give us a starting indication of how much is owed, if return is owed at all. As with the claim based on ownership, we are missing an account of when justice requires return of benefit in the first place.

\section{From Reciprocity}

One value or idea that might substantiate Indonesia's claims for a fair share of the benefits associated with participation in GISN is the idea of reciprocity. ${ }^{28}$ Unlike the previous accounts, the idea of reciprocity gives us an answer to the moral question of when return is owed. The idea of reciprocity is that when others gives good to you, you owe them fair return for what they have given you just as, when you give good to others, they owe you fair return for what you have given them. This idea, along with the others about contribution and ownership, supports the conclusion that $\mathrm{Z}$ (like $\mathrm{X}$ and $\mathrm{Y}$ ) is owed an equal share of the pie in return for her contribution to the pie-making process. In contributing a few stirs and a scoop of ice cream to the pie-making, $\mathrm{Z}$ gave good to $\mathrm{X}$ and $\mathrm{Y}$ and she is owed fair return - which, as we have suggested above, is an equal share of the pie - for these contributions.

Social rules should express and foster the idea of reciprocity. ${ }^{29}$ This means that social rules must be arranged so that they ensure that fair return is given to those who contribute to a cooperative process. If a set of social rules violate or fail to encourage the conditions of reciprocity, then they fail to meet a minimal standard of justice. For example, some have argued that social rules should be organized so that they give return to people for what they have contributed to society (through submission to a system of laws, social rules, or other means) and that any system that fails to do so is unjust. ${ }^{30}$

Taken in conjunction with the other arguments, the idea of reciprocity completes Indonesia's claim to a share of the benefits associated with GISN. We argued earlier that Indonesia's contribution was significant and would merit significant return, if return was owed to Indonesia in the first place. We now have reasons, related to the idea of reciprocity, for thinking that Indonesia was indeed owed return. Reciprocity dictates that 
Indonesia is owed fair return for the good that it gave to GISN and its participating members. Failing to properly reciprocate Indonesia's contribution would be unfair and hence a mark of injustice.

The trouble is that reciprocity, at least when it involves goods and resources in short supply and high demand, tends to fail in practice. Developed countries, for example, have delayed delivery of vaccines promised to the developing world, even when they have made significant contributions to global pandemic preparedness. ${ }^{31}$

\section{Human Rights as an Alternative Frame}

Intermingled with its claims of ownership and contribution Indonesia often highlighted how GISN facilitated access to goods such as vaccines for some, but not all. Specifically, Indonesia claimed that whereas GISN facilitated pandemic preparedness in developed countries, it failed to secure access to, or ameliorate the position of, developing countries lacking the resources for pandemic preparedness. As such, GISN was and remains unjust.

Although Indonesia articulated this access concern as a consequence of GISN's refusal to recognize its sovereign rights over virus specimens, or the necessity of its contribution to the global system, we think the concern about access merits independent consideration.

To begin, an argument based on access is more sweeping than the other claims made by Indonesia. It makes a case for all developing countries - not just Indonesiahaving greater access to the goods needed for pandemic preparedness, including, in the shorter term, access to any stockpiled vaccines and, in time, access to technology, infrastructure, and know-how needed in order to develop in-country vaccine research and development capacity.

This claim to greater access is also more straightforward than arguments based on ownership, contribution, and reciprocity. As we explained above, arguments based on ownership and contribution can tell us something about who is owed a return, but not when. Reciprocity supplies an answer to when fair return is owed but what you are owed depends on what you contribute and, in a world where capacity to contribute varies, reciprocity may not in the end achieve a more equitable distribution of goods. ${ }^{32}$

In contrast, within a human rights framework, equitable access to goods is precisely what justice requires. This is what our very "social and international order" exists to protect. ${ }^{33}$ As the United Nations Declaration on Universal Human Rights states,

Everyone is entitled to a social and international order in which the rights and freedoms set forth in this Declaration can be fully realized.

In order for human rights to be met, human beings must have access to basic goodssuch as those that are necessary for adequate health and survival - that are essential to a minimally dignified human life. Therefore, to the extent that a rule, practice, or system secures access to those goods for some, but not all, it is unjust.

From a human rights perspective, then, GISN can be understood as an example of a set of social rules that have not met this minimal requirement of justice. In particular, the rules, policies, and practices bound up in GISN, appear to have helped some, but not 
all, to prepare for and address a pandemic threat. The system failed to ensure that those in a position of wealth transferred or shared resources necessary for health and survival with those in a position of need.

Despite the apparent force of this kind of critique of GISN, Indonesia curiously stopped short of explicitly invoking human rights. For a time, there was rumour that Viet Nam and Thailand might join Indonesia in its stance. When they did not do so, perhaps Indonesia was less inclined to make a claim on behalf of all developing countries. Or, perhaps Indonesia resolved to rely primarily on assertions of ownership under the $C B D$ because claims of legal ownership were anticipated to be what more developed countries understand and respect.

It may be bold of us to second-guess such strategic questions in retrospect. However, we believe that, in framing its concerns in terms of human rights, Indonesia could have precipitated a different policy dialogue and set of proposals than what we have thus far seen. A human rights frame would have directed attention to other contexts in which the interests of wealthier governments and multinational companies, on the one hand, and developing countries and the world's poor on the other, have clashed. Take HIV/AIDS in sub-Saharan Africa - a pandemic of significantly greater, and present, proportions than influenza. Notwithstanding an international declaration empowering countries to override intellectual property rights for the purpose of addressing national health needs, and at least one national law crafted specifically to facilitate access to HIV/AIDS drugs, countries' authority to secure access to the necessary goods continues to be questioned. Framing the issue in terms of human rights would have highlighted how poorly reconciled they are with intellectual property rights and, for that reason, motivated a different policy conversation about what benefit-sharing under GISN should look like.

\section{What Way Forward?}

In the end, Indonesia's claims about unjust benefit sharing in GISN can be grouped into one of two categories. The first category of claims, ties together the values of ownership, contribution, and reciprocity, to ground the conclusion that Indonesia is entitled to an equal share of benefits. The second category of claims, derived from the value of human rights, holds that developing countries, in general, are entitled to an equitable share of benefits. As shown above, we are of the view that both categories of claims have merit.

There are many reasons to be sceptical that any of the underlying values will gain traction. We suspect the issue of ownership will continue to be mired in legal uncertainty. We suspect that the powerful will determine what metric will be used to evaluate contributions to global pandemic preparedness, limiting the returns to those whose inputs are necessary but small, or big but only relative to capacity. We suspect that notions of reciprocity may work well where communicating information is what is required, but not when tangible goods and resources such as vaccines and healthcare providers are involved. And we also suspect that human rights are an all-too familiar refrain in international relations and global justice discourse. 
Even so, when the World Health Assembly reconvenes in May 2011, we believe a just framework for benefit sharing in GISN depends on taking all of these values - from ownership, contribution, reciprocity, to human rights - into account.

The framework that is currently proposed, comprised of a standardized MTA and accompanying set of benefit-sharing principles, fails to do so. First, the MTA promotes a free-for-all approach to ownership, allowing anyone and everyone to apply for intellectual property rights. This does nothing to recognize the ownership interests of those providing virus specimens while preserving the status quo for those already expert in seizing and marshalling intellectual property to their advantage. Second, while virus samples are implicitly recognized as necessary inputs to GISN, compensation is not calibrated according to the contributing country's capacity. Rather, return is to be negotiated on an ad hoc basis, between third parties availing of materials from GISN and source countries. ${ }^{34}$ Third, benefit-sharing in practice is thus contingent on goodwill between the parties, fragile in the context of a pandemic, rather than obligations of reciprocity. Fourth, and finally, human rights are nowhere to be found in the MTA or benefit-sharing principles.

The absence of human rights language in the framework is particularly telling. Human rights requires that all people, independent of whether they contribute to GISN, have access to vaccines and other goods that are needed to satisfy their human right to health. In a world in which vaccine manufacturing and distribution capacity is in limited supply, ${ }^{35}$ those human rights obligations cannot be met. Enhancing, diversifying, and building vaccine manufacturing and distribution capacity is, therefore, where we believe the policy discussion and the WHO's framework for access to virus and other benefits must go. "An agreement to agree" about transferring vaccine manufacturing know-how to developing countries, one amongst several benefit sharing "arrangements" that the WHO cannot oblige, but hopes, public institutions and private manufacturers will make, does not do enough. 
Figure 1.

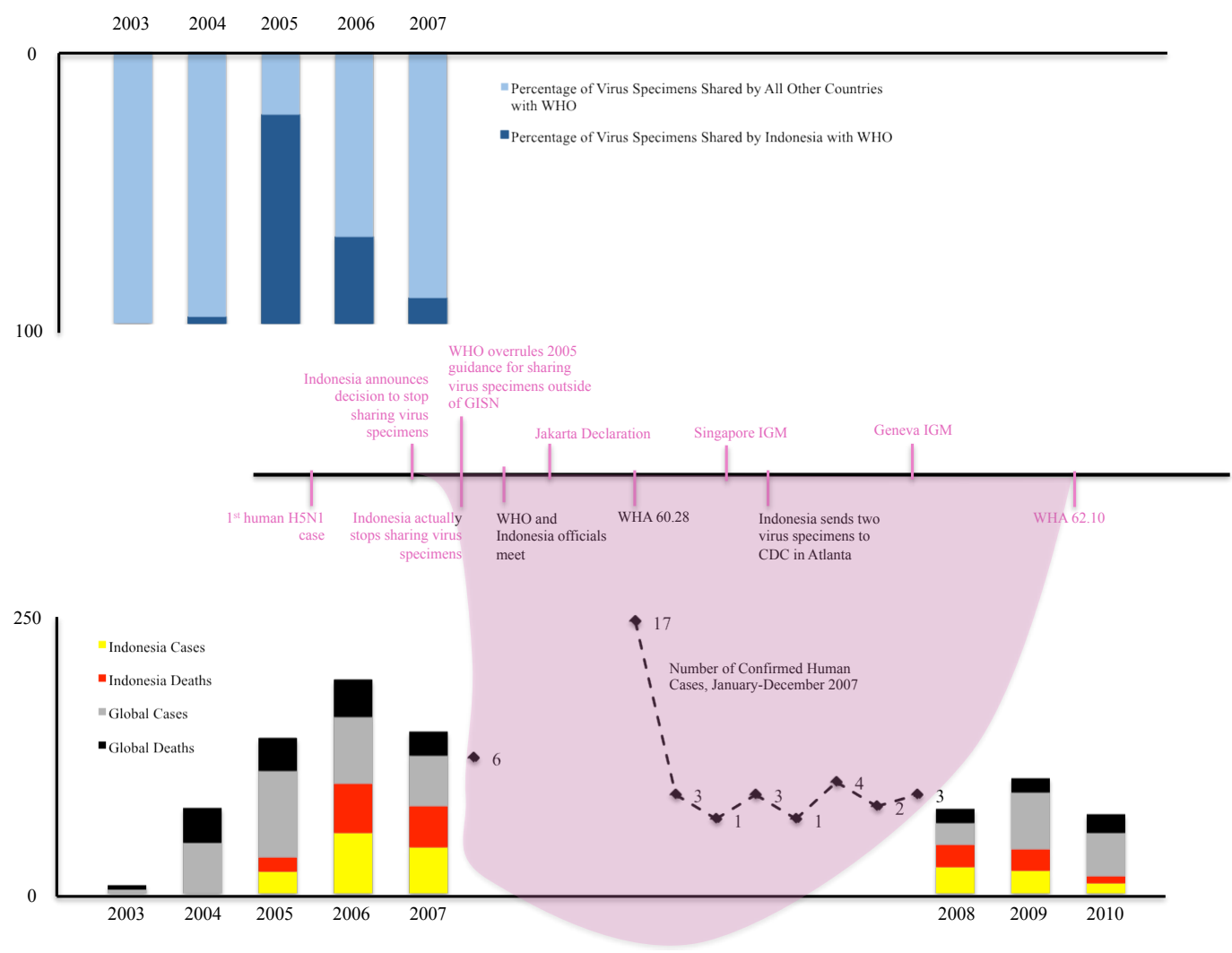


Figure 2.

\section{Diverging Positions of \\ Member Countries}

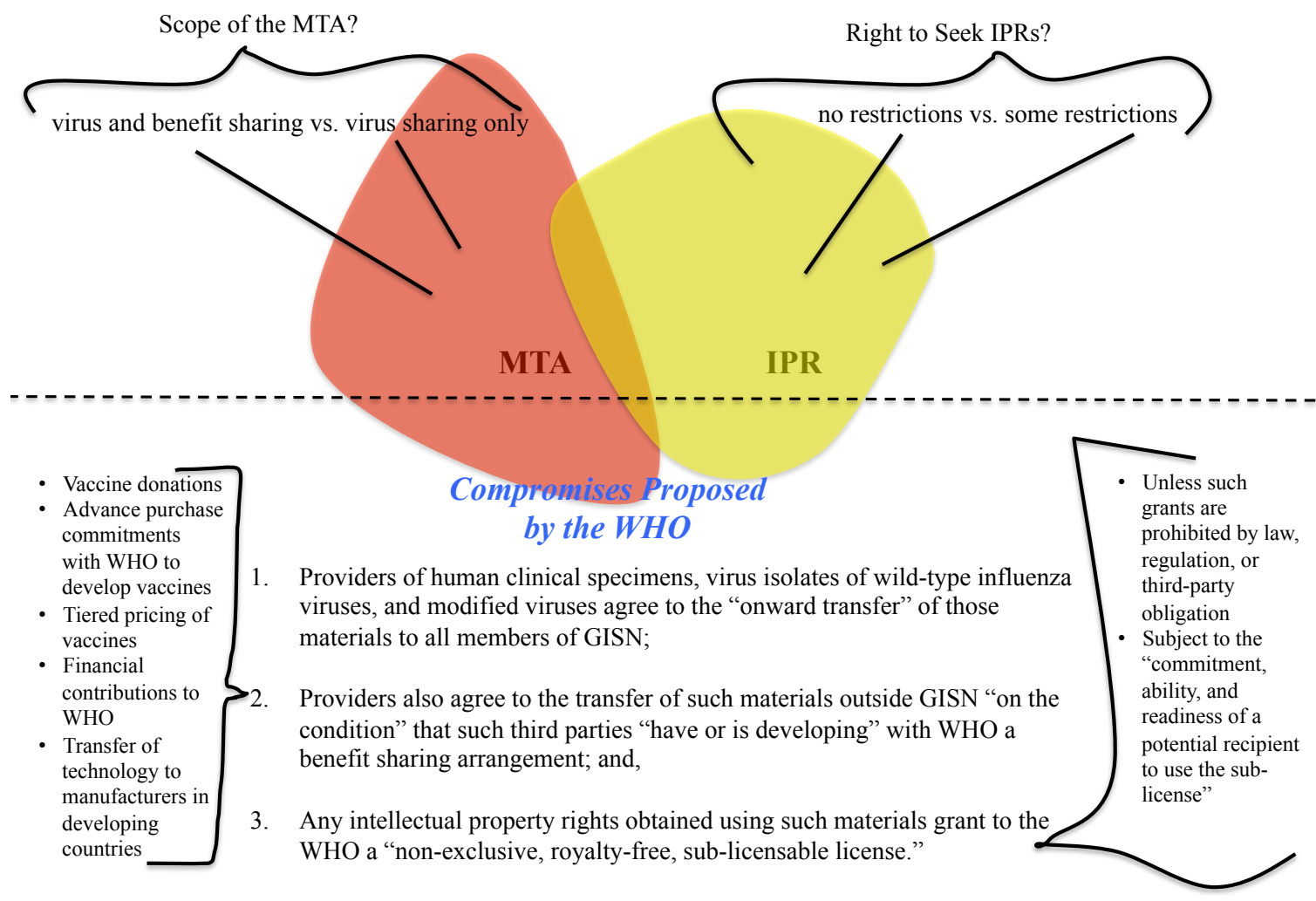


${ }^{1}$ David P. Fidler, "Indonesia's Decision to Withhold Influenza Virus Samples from the World Health Organization: Implications for International Law," American Society of International Law, 11, no. 4 (2007), at http://www.asil.org/insights070227.cfm.

${ }^{2}$ World Health Assembly, WHA 60.28, Pandemic Influenza Preparedness: Sharing of Influenza Viruses and Access to Vaccines and Other Benefits (23 May 2007).

${ }^{3}$ David P. Fidler, "Negotiating Equitable Access to Influenza Vaccines: Global Health Diplomacy and the Controversies Surrounding Avian Influenza H5N1 and Pandemic Influenza H1N1," PLoS Medicine, 7, no. 5 (2010): 1-4.

${ }^{4}$ Simone Vezzani, "Preliminary Remarks on the Envisaged World Health Organization Pandemic Influenza Preparedness Framework for the Sharing of Viruses and Access to Vaccines and Other Benefits," The Journal of World Intellectual Property, 13, no. 6 (2010): 675-696.

${ }^{5}$ Endang R Sedyaningsih, Siti Isfandari, Triono Soendoro, Siti Fadilah Supari, "Towards Mutual Trust, Transparency and Equity in Virus Sharing Mechanism: The Avian Influenza Case of Indonesia," Annals of Academic Medicine Singapore 37, no. 6 (2008): $482-488$, at 485.

${ }^{6}$ The information contained in Figure 1 is derived from a variety of sources compiled by the WHO, at http://www.who.int/csr/disease/avian influenza/country/en/.

${ }^{7}$ See Sedyaningsih et al., "Towards Mutual Trust," 486. According to reports, CSL later produced a vaccine known as Panvax ${ }^{\circledR}$ to be used for Australians in the event of an H5N1 pandemic. In 2008, other companies pledged large donations of vaccines to a WHO stockpile. See Kunal Rambhia, "H5N1 News: Australia Approves Vaccine; Sanofi to Donate to WHO Stockpile; HHS Contracts to Develop Rapid Diagnostic Tests," Biosecurity News in Brief, June 20, 2008, at http://www.upmcbiosecurity.org/website/biosecurity_briefing/archive/avian_pandemic_flu/2008/2008-0620-h5n1newsaustraliasanofihhs.html.

${ }^{8}$ Edward Hammond, Some Intellectual Property Issues Related to H5N1 Viruses, Research, and Vaccines (Penang: Third World Network, 2009), at http://www.twnside.org.sg/title2/avian.flu/papers/patent.paper.pdf; World Intellectual Property Organization, Working Paper: Patent issues related to influenza viruses and their genes (2007), at http://www.who.int/csr/disease/avian influenza/wipo ipdoc/en/index.html.

${ }^{9}$ See Sedyaningsih et al., "Towards Mutual Trust," 486.

${ }^{10}$ David P. Fidler, "Influenza Virus Samples, International Law, and Global Health Diplomacy," Emerging Infectious Diseases 14, no. 1 (2008): 88-94, at 89.

${ }^{11}$ WHA 60.28 .

${ }^{12}$ Sedyaningsih et al., "Towards Mutual Trust," 486.

${ }^{13}$ Deborah Cohen and Philip Carter, "WHO and the Pandemic Flu 'Conspiracies'," BMJ 340 (2010): 1274-1279.

${ }^{14}$ Catherine Saez and William New, "WHO Future in Question; Debate over Industry Representation," Intellectual Property Watch, at http://www.ip- 
watch.org/weblog/2011/01/17/who-future-in-question-debate-over-industryrepresentation/.

${ }^{15}$ World Health Assembly, WHA 62.10, Pandemic Influenza Preparedness: Sharing of Influenza Viruses and Access to Vaccines and Other Benefits (22 May 2009).

${ }^{16}$ For a detailed discussion about the legal basis upon which the WHO might implement the proposed virus and benefit sharing framework, and the apparent preferences of some member states for binding versus non-binding approaches, see Vezzani, "Preliminary Remarks," 683-685.

${ }^{17}$ Compare, for example, the language proposed by member states in the WHO African Region (WHO, Intergovernmental Meeting on Pandemic Influenza Preparedness: Sharing of Influenza Viruses and Access to Vaccines and Other Benefits (4 January 2008), p. 10, article 4) with the language of article 6.3 in WHO document A62/5 quoted in Vezzani, "Preliminary Remarks," 682, versus the language of article 3.1.3 in WHO document EB126/4 (WHO, Executive Board, $126^{\text {th }}$ Session, 10 December 2009, at http://apps.who.int/gb/ebwha/pdf files/EB126/B126 4-en.pdf).

${ }^{18}$ Filder, "Indonesia's Decision," 3.

${ }^{19}$ We hasten to point out that calls for equity and justice in a national context have had little purchase. See Lori Uscher-Pines, Patrick S. Duggan, Joshua P. Garoon, Rith A. Karron, and Ruth R. Faden, "Planning for an Influenza Pandemic: Social Justice and Disadvantaged Groups" Hastings Center Report 37, no. 4 (2007): 32-39.

${ }^{20}$ Fidler "Influenza Virus Samples," 93.

${ }^{21}$ Though these will not be our focus, it is important to note that worries about injustice were not the only factors motivating Indonesia's actions. In-depth, after-the-fact analyses of the Indonesian saga reveal that nationalism, religion, even political ambition, also figured in the Health Minister's decision to stop sharing virus specimens. See Paul Forster, "The Political Economy of Avian Influenza in Indonesia," STEPS Center, 2009, 46-49, at www.steps-centre.org/PDFs/Indonesia.pdf.

${ }^{22}$ Convention on Biological Diversity. 2005. DecisionII/11. Access to Genetic Resources. Montreal: UNEP/CBD: paragraph 2. "The [Conference of the Parties] [re]affirms that human genetic resources are not included within the framework of the Convention."

${ }^{23}$ Fidler, "Indonesia' Decision"; Fidler, "Influenza Virus Samples," 90-91; Vezzani, "Preliminary Remarks," 678-79. Note, however, that if "fair and equitable sharing of benefits from the use of genetic resources," which is included in the CBD's preamble, is construed as a primary object of the convention, then we might conclude differently. ${ }^{24}$ World Health Organization, Global Alert and Response, "A Description of the Process of Seasonal and H5N1 Influenza Vaccine Virus Selection and Development," (19 November 2007), at: http://www.who.int/csr/disease/avian_influenza/influenza_vaccineVirus_slection/en/index.html.

${ }^{25}$ In some cases, "ownership" might in itself determine when compensation is owed. However, we are strictly concerned with cases of voluntary transfer and when compensation for such transfer is owed. Our claim is that, in such cases, "ownership" is not in itself enough to establish when compensation is owed. 
${ }^{26}$ World Health Organization, "A Summary of Tracking Avian Influenza A(H5N1) Specimens and Viruses Shared with WHO from 2003 to 2007," (31 January 2008) at: http://www.who.int/csr/disease/avian influenza/aivirus tracking summary/en/index.html

${ }^{27}$ What exactly counts as "equal" will likely depend on the context. In the case of vaccine, it may, for example, be relative to population size.

${ }^{28}$ Members of the media also seemed to support the notion of justice as requiring reciprocity. For example, see Claudia D. Surjadjaja, "Vaccines and the Justice of Reciprocity," The Jakarta Post, March 12, 2007.

${ }^{29}$ Though in different ways, David Schmidtz, The Elements of Justice (Cambridge: Cambridge University Press, 2006), 73-106, Andrea Sangiovanni, "Global Justice and the State," Philosophy and Public Affairs 35, no. 1 (2007): 3-39, and Lawrence C. Becker, Reciprocity (New York: Routledge Kegan Paul, 1986) claim that reciprocity is an essential element of justice.

${ }^{30}$ See n. xxix.

${ }^{31}$ Fidler, "Negotiating Equitable Access," 2.

${ }^{32}$ A related point is made by Allen Buchanan who argues that reciprocity cannot be the full basis for claims of (domestic) justice. See his, "Justice as Reciprocity versus Subject-Centered Justice," Philosophy and Public Affairs, 19, no. 3 (1990): 227-252.

${ }^{33}$ Using the Indonesian case to contextualize their inquiry, others have highlighted various human rights instruments that have, since the passage of the Universal Declaration in 1948, attempted to entrench this goal. See Doris Schroeder and Eugenijus Gefenas, "Realizing Benefit Sharing-The Case of Post-Study Obligations," forthcoming in Bioethics (2011).

${ }^{34}$ Unequal bargaining power between the parties and the lack of specificity of the benefit sharing principles are reasons to doubt of the efficacy of the proposed framework. See Vezzani, "Preliminary Remarks," 681, 683.

${ }^{35}$ Although progress has been made since the Global pandemic influenza Action Plan to increase vaccine supply (known as the "GAP") was published by the WHO in 2006, production power remains far short of global need and highly concentrated in developed countries. See Jeffrey Partridge and Marie Paule Kieny, "Global Production of Seasonal and Pandemic (H1N1) Influenza Vaccines in 2009-2010 and Comparison with Previous Estimates and Global Action Plan Targets," Vaccine 28, no. 30 (2010): 4709-4712. 